\title{
The Effect of Mathematics Teachers' Self-Efficacy and Leadership Styles on Students' Mathematical Achievement and Attitudes
}

\author{
By Tevfik Küçükalioğlu* \& Güler Tuluk ${ }^{\dagger}$
}

\begin{abstract}
The aim of this study was to examine the effect of middle school mathematics teachers' self-efficacy and leadership styles on middle school students' mathematical achievements and attitude towards mathematics. In this study, the general survey method was employed and the research population was consisted of a total of 917 , 5th grade students, 472 girls and 455 boys, picked across 10 middle schools in a central district of a province located in North-West Anatolia. In order to gather scientific data, scales such as Mathematics Attitude Scale, Teacher's Self-Efficacy Scale, and Mathematics Achievement Test were used. Teacher characteristics were divided into two categories which consist of two and three sub-categories respectively; autocratic and semidemocratic based on the Leadership Style Scale. And low, moderate, high level according to teachers' scores in the Self-Efficacy Scale. The data obtained were analysed in accordance with the objectives by means of frequency, percentage, arithmetic mean, standard deviation, $t$ test, one-way variance analysis (Ancova). The significance level in statistical analyses was set at $\mathrm{p}<0.05$. Consequently, whether the teachers displayed low or high leadership styles had no significant effect on the students' mathematical achievement and their attitude towards the subject. Teachers' self-efficacy for classroom management sub-scale was found to have an effect on the mathematical achievement of students. The self-efficacy level of teachers for student engagement does not have a significant effect on students' mathematical achievement. However, it was found that teachers' self-efficacy for instructional behaviour, classroom management and student management affected students' attitude towards mathematics.
\end{abstract}

Keywords: Mathematical achievement, attitude towards mathematics, Teachers' SelfEfficacy, Leadership Styles of Teachers.

\section{Introduction}

Mathematics is one of the most important subjects students have to learn at school. Mathematics is a human activity, so the student must be a part of it. Instead of memorizing some rules, students can learn mathematics in a social environment by constructing mathematical concepts and relations themselves. Mathematics includes quantity, structure, space, and change. While the place of mathematics in this changing world has moved out of itself today and affects school mathematics, this effect has also expanded in school mathematics, from science and technology to society and culture, and into daily life with personal health and finance.

Apart from biological trends and knowledge structures, mathematics competence also depends on sociocultural influences (Cobb, 1994). One does not pass the mathematics knowledge passively from the environment just like other

\footnotetext{
*Mathematics Teacher, Kastamonu University, Turkey.

${ }^{\dagger}$ Associate Professor, Kastamonu University, Turkey.
} 
forms of knowledge; constructs the teacher as a result of interactions with classmates and other individuals.

Closing the long existing achievement gap between students of high and low achievement in mathematics classes has been vital for the member countries of EU, as well as Turkey (Eurydice, 2011). This existing need for mathematics knowledge and its usage has brought about other variables such as self-efficacy, self-regulation, demeanour etc., as a result of the advancements in learning theories (Schunk, 2009).

It is also an important component of attitude towards mathematics in mathematics teaching studies. Attitude; It refers to a tendency that is attributed to a person and regularly creates his emotions, thoughts and behaviors related to an object (Kağıtçıbaşı, 1979).

Students' attitudes towards mathematics are very important in mathematics education. Studies (Bloom, 1995) show that about a quarter of the differences between an individual's learning come from affective features. Developing a positive attitude towards mathematics is one of the most important goals of mathematics education (Reyes, 1984). Ministry of National Education (MEB, 2013) Course in Elementary Mathematics Program is also located in Turkey this purpose.

Self-efficacy is the belief in one's own capacity to bring Learning and behavior to the required levels (Bandura, 1977a, 1977b, 1986, 1993, 1997). Selfefficacy is what one thinks is sufficient to do; is very different from knowing what to do. It is the evaluation of individuals' self-efficacy, skills and capacities and turning them into behavior. Self-efficacy has an important place in gaining self (Bandura, 1997, 2001). Self-efficacy also includes teachers (Pajares, 1996; Tschannen- Moran, Woolfolk Hoy, \& Hoy, 1998).

High self-efficacy ensures motivation continues. When individuals reach their goals, they also tend to achieve more goals (Schunk, 1989). Self-efficacy greatly affects effort and commitment (Bandura \& Cervone, 1983, 1986; Schunk, 1995). Individuals with high self-efficacy spend more effort when faced with difficulty and become more dependent on the challenge when they have the necessary skills.

Social Cognitive Theory and Humanistic Learning Theories have changed the understanding of being a mathematics teacher in Turkey schools'. MEB (2009) programs and the place of the teacher, who assumed the role of knowledge transfer expert; a. Teaching and learning, b. Observing, controlling and improving teaching, c. Continuing its education and professional development, d. Working together to succeed, e. He has evolved to change as a teacher who thinks deeply.

Being a mathematics teacher, one can say that self-efficacy perceptions affect the purpose and the nature of the function that teachers desire to fulfil. The behaviour of one such individual exerts influence on a classroom, having an effect on the students' satisfaction, motivation and performance.

Furthermore, the subject-matter knowledge, pedagogical content knowledge, ability, talent and the personality characteristics of a mathematics teacher have a direct impact on students. The main role of the mathematics teacher is to make the subject easier to comprehend. Students are both responsible and active when learning mathematics. The self-efficacy of the teacher is a variable in trying to 
maintain the efficiency in terms of input and output during this process. Thus, the effects that this variable has on achievement and attitude should be further scrutinized.

Under these circumstances, we should not only look for the students' thoughts, beliefs, attitudes and roles of their values, but also the factors that determine the effect of their teachers in these roles. Consequently, self-efficacy perceptions and leadership styles of mathematics teachers in Turkey are points that are worth stressing at this point.

In this study, the aim was to investigate the effect of teacher characteristics on fifth grade students' attitudes towards mathematics and mathematical achievement and answers to the following questions were sought.

1. Does the mathematical achievement of fifth grade students in middle school differ according to the leadership styles of mathematics teachers?

2. Does the attitude of fifth grade middle school students towards mathematics differ according to the leadership styles of mathematics teachers?

3. Does the mathematical achievement of fifth grade students in middle school differ according to the self-efficacy of mathematics teachers?

i. Is there a significant difference between teachers' self-efficacy for student engagement and students' mathematical achievement?

ii. Is there a significant difference between teachers' self-efficacy for instructional strategies and mathematical achievement of students?

iii. Is there a significant difference between teachers' self-efficacy for classroom management and mathematical achievement of students?

4. Does the attitude of fifth grade middle school students towards mathematics change based on the self-efficacy of the mathematics teachers?

i. Is there a significant difference between teachers' self-efficacy for student engagement and students' attitude towards mathematics?

ii. Is there a significant difference between teachers' self-efficacy for instructional strategies and students' attitude towards mathematics?

iii. Is there a significant difference between teachers' self-efficacy for classroom management and students' mathematical success?

\section{Literature Review}

Studies generally show the effects of students' self-efficacy beliefs on their academic achievement and performance (Denise \& O'Neil, 1997; Malpass, O'Neil, \& Hocevar, 1996), and teachers'/prospective teachers' self-efficacy for teaching/ learning. It also shows the effects of beliefs (Andersen, Evans, \& Serensen, 2003; Huinker \& Madison, 1997) and gender difference on self-efficacy towards learning/ teaching and computers (Aşkar \& Umay, 2001). In some studies, it has been emphasized that the development of self-efficacy in the individual will increase the performance of the individual (Stajkovic \& Luthans, 1998; Tuckman \& Sexton, 1990). At the same time, it is emphasized that self-efficacy belief can be directly developed in the studies (Eden \& Aviram, 1993; Bandura, 1986). 
In many studies, it has been determined that teachers with high self-efficacy beliefs show more effort in teaching, are more willing in the learning-teaching process, are more successful in the selection of methods and techniques, and in summary, in implementing the curriculum (Friedman \& Kass, 2002; TschannenMoren \& Woolfolk, 2001).

Gibson and Dembo (1984) state that a teacher with a high self-efficacy belief is more willing in the classroom, uses time by planning better and works longer.

\section{Methodology}

In the general survey model, in a universe consisting of many elements, the whole universe or a group of samples or samples to be taken from it is scanned in order to make a general judgment about the universe (Karasar, 2007). There is never an effort to alter or affect the research subject.

\section{Research Population}

The population of the study was consisted of fifth grade students and their teachers in 2013-2014 academic year, which were picked across 10 different middle schools within the borders of a province located in North-West Anatolia.

Of the 917 students participating in the research, 51.4\% (472) were female and $48.6 \%$ (445) were male. The data were collected from fifth grade middle school students and their mathematics teachers in nine schools.

\section{Survey Scales}

Within the scope of this study, four different scales, namely; "Mathematics Achievement Test" (MAT), "Teachers' Efficacy Beliefs System-Self Form" as adopted by Baloğlu and Karadağ (2008) and its reliability re-tested by Tuluk (2015), "Mathematics Attitude Scale" (MAS) developed by Nazliçiçek and Erktin (2002), and "Teacher Leadership Style Scale" developed by Deniz and Hasançebioğlu were used. The mathematics achievement test (MAT) was developed by the researchers (Cronbach-Alfa, 0.84).

\section{Application of Data-Collecting Instruments and Analysis}

Prior to the survey, the administration of the schools and the mathematics teachers taking part in the survey were consulted and necessary appointments were taken. Mathematics Achievement Pretest and Mathematics Pretest Attitude Scale were applied in two different forms: First, as pretests in the second term of 20132014, pre-test between 10-15 February, 2014 academic year and as posttests between 26-30 May, 2014. Twenty mathematics teachers in their respective 
schools took part in the Teacher Leadership Style Scale and Teacher Self-Efficacy Survey between 2-7 June 2014. The data collected were analysed via the statistic program SPSS 19.0 on a computer (significance level set at <.05)

\section{Findings/Results}

\section{Research Questions}

The Pearson Correlation Analysis results regarding the question, "Is there a correlation between the mathematical success of students and their attitude towards mathematics?" are shown on Table 1.

Table 1. Correlation Analysis Results

\begin{tabular}{|lll|c|c|}
\hline Test Pair & r & p \\
\hline MAchPreT (Achievement & Pretest) & -MAttPreS (Attitude & 0.383 & $<0.001$ \\
\hline MAchPostT (Achievement & Posttest)-MAttPostS (Attitude & 0.385 & $<0.001$ \\
\hline
\end{tabular}

Analysis of the results on Mathematical Achievement Pretest and Mathematics Attitude Pretest showed that there was a moderate relationship between the values found after the analysis $(r=0.383$. $p<0.001)$. The same correlation proved to be correct in the case of Mathematical Achievement Posttest and Mathematics Attitude Posttest scores ( $\mathrm{r}=0.385$. $\mathrm{p}<0.001)$.

1. Findings on the sub-research question, "Does the mathematical achievement of fifth grade students in middle school differ according to the leadership styles of mathematics teachers?"

The first sub-research question of the study was described as the following: "Is there a significant relationship between the pretest and the corrected posttest scores of the mathematical achievement test of students that have teachers who display autocratic or semi-democratic teacher leadership styles?"

An ANCOVA test was performed on the Mathematical Achievement posttest scores of students, whose mathematics teachers displayed autocratic or semidemocratic leadership styles. Posttest scores of two student groups prior to test are given in Table 2.

Table 2. The Results of the ANCOVA Test on the Changes in Mathematics Achievement Test Scores According to Teachers' Leadership Style

\begin{tabular}{|l|c|c|c|c|c|}
\hline Source & Type III Sum of & SD & Mean & F & P \\
\hline $\begin{array}{l}\text { Corrected } \\
\text { Model }\end{array}$ & $22538,202^{\mathrm{a}}$ & 2 & 11269.101 & 418.355 & .000 \\
\hline Intercept & 2039.305 & 1 & 2039.305 & 75.707 & .000 \\
\hline TEST1 & 22510.494 & 1 & 22510.494 & 835.681 & .000 \\
\hline Leadership & 59.372 & 1 & 59.372 & 2.204 & .138 \\
\hline
\end{tabular}




\begin{tabular}{|l|c|c|c|l|l|}
\hline Error & 24620.156 & 914 & 26.937 & & \\
\hline Total & 295115.000 & 917 & & & \\
\hline Corrected Total & 47158.358 & 916 & & & \\
\hline
\end{tabular}

Based on the results of the ANCOVA test given in Table 2, there is no significant difference between the pretest scores and the corrected posttest average scores of students in different groups $(\mathrm{F}(914 ; 1)=2.204 . \mathrm{p}>0.05)$. Thus, it is possible to say that the leadership styles of the teachers have no impact on the mathematical achievement of students.

Table 3. The Results of the ANCOVA Test on the Changes in Mathematics Attitude Scale Scores According to Teachers' Leadership Style

\begin{tabular}{|l|c|c|c|c|c|}
\hline Source & $\begin{array}{c}\text { Type III Sum of } \\
\text { Squares }\end{array}$ & sd & Mean Square & F & P \\
\hline Corrected Model & $30727.592^{\mathrm{a}}$ & 2 & 15363.796 & 156.471 & .000 \\
\hline Intercept & 21012.403 & 1 & 21012.403 & 213.999 & .000 \\
\hline ATTITUDE1 & 30611.420 & 1 & 30611.420 & 311.760 & .000 \\
\hline $\begin{array}{l}\text { Management } \\
\text { Style }\end{array}$ & 233.703 & 1 & 233.703 & 2.380 & .123 \\
\hline Error & 89744.861 & 914 & 98.189 & & \\
\hline Total & 5185868.000 & 917 & & & \\
\hline Corrected Total & 120472.454 & 916 & & & \\
\hline
\end{tabular}

a. $R$ Squared $=.255$ (Adjusted $R$ Squared $=.253$ )

Based on the results of the ANCOVA test given in Table 3, there is no significant difference between the pretest scores and the corrected posttest average scores of students in different groups $(\mathrm{F}(914 ; 1)=2,380, \mathrm{p}>0.05)$. Consequently, it can be concluded that teachers' leadership styles do not affect the students' attitude towards mathematics.

2. Findings on the sub-research questions, "Does the mathematical achievement of fifth grade students in middle school differ according to the self-efficacy of mathematics teachers?"

Table 4. The Results of the ANCOVA Test on the Changes in Mathematics Attitude Scale Scores According to High and Low Self-Efficacy Levels of the Teachers

\begin{tabular}{|l|c|c|c|c|c|}
\hline Source & $\begin{array}{c}\text { Type III Sum } \\
\text { of Squares }\end{array}$ & sd & Mean Square & F & P \\
\hline Corrected Model & $22724.577^{\mathrm{a}}$ & 2 & 11362.289 & 425.032 & .000 \\
\hline Intercept & 2200.718 & 1 & 2200.718 & 82.323 & .000 \\
\hline
\end{tabular}




\begin{tabular}{|l|c|c|c|c|c|}
\hline TEST1 & 21916.608 & 1 & 21916.608 & 819.840 & .000 \\
\hline Self-Efficacy & 245.746 & 1 & 245.746 & 9.193 & .002 \\
\hline Error & 24433.781 & 914 & 26.733 & & \\
\hline Total & 295115.000 & 917 & & & \\
\hline Corrected Total & 47158.358 & 916 & & & \\
\hline
\end{tabular}

a. $R$ Squared $=.482($ Adjusted $R$ Squared $=.481)$

As per the results of the ANCOVA test given in Table 4, there is a significant difference between the pretest scores and the corrected posttest average scores of students in different groups $(\mathrm{F}(914 ; 1)=9.193, \mathrm{p}<0.02)$.

Further ANCOVA tests were conducted on each sub-research question to find out whether this situation was the result of the self-efficacy score or the outcome of a sub-research question regarding self-efficacy in particular.

i. Findings on the sub-research question regarding Mathematical Achievement and Teachers' Self-Efficacy for Instructional Strategies

Table 5. The Results of the ANCOVA Test on the Changes in Mathematics Achievement Test Scores According to Teachers' Self-Efficacy for Instructional Strategies

\begin{tabular}{|l|c|c|c|c|c|}
\hline Source & $\begin{array}{c}\text { Type III Sum } \\
\text { of Squares }\end{array}$ & sd & $\begin{array}{c}\text { Mean } \\
\text { Square }\end{array}$ & F & P \\
\hline Corrected Model & $22577.258^{\mathrm{a}}$ & 2 & 11288.629 & 419.746 & .000 \\
\hline Intercept & 2150.242 & 1 & 2150.242 & 79.953 & .000 \\
\hline TEST1 & 22236.443 & 1 & 22236.443 & 826.819 & .000 \\
\hline $\begin{array}{l}\text { Self-Efficacy for } \\
\text { Instructional } \\
\text { strategies }\end{array}$ & 98.427 & 1 & 98.427 & 3.660 & .056 \\
\hline Error & 24581.100 & 914 & 26.894 & & \\
\hline Total & 295115.000 & 917 & & & \\
\hline Corrected Total & 47158.358 & 916 & & & \\
\hline
\end{tabular}

a. $R$ Squared $=.479($ Adjusted $R$ Squared $=.478)$

In accordance with the ANCOVA test results given in Table 5, there is no significant difference between the pretest scores and the corrected posttest average scores of students in different groups $(\mathrm{F}(914 ; 1)=3.660, \mathrm{p}>0.05)$. Hence, it is possible to say that the teachers' self-efficacy level in instructional strategies does not affect the academic achievement of students in mathematics.

ii. Findings on the sub-research question regarding Mathematical Achievement and Teachers' Self-Efficacy for Classroom Management 
Table 6. The Results of the ANCOVA Test on the Changes in Mathematics Achievement Test Scores According to Teachers' Self-Efficacy for Classroom Management

\begin{tabular}{|l|c|c|c|c|c|}
\hline Source & $\begin{array}{c}\text { Type III Sum of } \\
\text { Squares }\end{array}$ & sd & Mean Square & F & P \\
\hline Corrected Model & $22869.582 \mathrm{a}$ & 2 & 11434.791 & 430.297 & .000 \\
\hline Intercept & 2146.817 & 1 & 2146.817 & 80.786 & .000 \\
\hline TEST1 & 22171.582 & 1 & 22171.582 & 834.329 & .000 \\
\hline $\begin{array}{l}\text { Self-Efficacy for } \\
\text { Classroom } \\
\text { Management }\end{array}$ & 390.751 & 1 & 390.751 & 14.704 & .000 \\
\hline Error & 24288.776 & 914 & 26.574 & & \\
\hline Total & 295115.000 & 917 & & & \\
\hline Corrected Total & 47158,358 & 916 & & & \\
\hline
\end{tabular}

a. $R$ Squared $=.485$ (Adjusted $R$ Squared $=.484$ )

Based on the results of the ANCOVA test given in Table 6, there is a significant difference between the pretest scores and the corrected posttest average scores of students in different groups $(\mathrm{F}(914 ; 1)=14.704, \mathrm{p}<0.01)$. As per the findings, we can conclude that the self-efficacy level of teachers in classroom management has an effect on students' academic achievement in mathematics.

iii. Findings on the sub-research question regarding Teachers' Self-Efficacy for Student Engagement in Mathematical Achievement

Table 7. The Results of the ANCOVA Test on the Changes in Mathematics Attitude Scale Scores according to Teachers' Self-Efficacy for Student Engagement

\begin{tabular}{|l|c|c|c|c|c|}
\hline Source & $\begin{array}{c}\text { Type III Sum of } \\
\text { Squares }\end{array}$ & sd & Mean Square & F & P \\
\hline Corrected Model & $22554.731 \mathrm{a}$ & 2 & 11277.365 & 418.943 & .000 \\
\hline Intercept & 2226.030 & 1 & 2226.030 & 82.695 & .000 \\
\hline TEST1 & 22550.989 & 1 & 22550.989 & 837.747 & .000 \\
\hline $\begin{array}{l}\text { Self-Efficacy for } \\
\text { Student } \\
\text { Engagement }\end{array}$ & 75.900 & 1 & 75.900 & 2.820 & .093 \\
\hline Error & 24603.627 & 914 & 26.919 & & \\
\hline Total & 295115.000 & 917 & & & \\
\hline Corrected Total & 47158.358 & 916 & & & \\
\hline
\end{tabular}

a. $R$ Squared $=.478($ Adjusted $R$ Squared $=.477)$ 
In accordance with the ANCOVA test results given in Table 7, there is no significant difference between the pretest scores and the corrected posttest average scores of students in different groups $(\mathrm{F}(914 ; 1)=2.820, \mathrm{p}>0.05)$. In tandem with the abovementioned findings, it is reasonable to say that teachers' self-efficacy for student engagement had no significant effect on students' mathematical achievement.

3. Findings on the sub-research questions, "Does the attitude of fifth grade students towards mathematics in middle school differ according to the selfefficacy of mathematics teachers?"

Table 8. The Results of the ANCOVA Test on the Changes in Mathematics Attitude Scale Scores based on High and Low Self-Efficacy of the Teachers

\begin{tabular}{|l|c|c|c|c|c|}
\hline Source & $\begin{array}{c}\text { Type III Sum of } \\
\text { Squares }\end{array}$ & sd & Mean Square & F & P \\
\hline Corrected Model & $33596.720 \mathrm{a}$ & 2 & 16798.360 & 176.732 & .000 \\
\hline Intercept & 20542.452 & 1 & 20542.452 & 216.123 & .000 \\
\hline Attitude & 30046.236 & 1 & 30046.236 & 316.110 & .000 \\
\hline Self-Efficacy & 3102.830 & 1 & 3102.830 & 32.644 & .000 \\
\hline Error & 86875.734 & 914 & 95.050 & & \\
\hline Total & 5185868.000 & 917 & & & \\
\hline Corrected Total & 120472.454 & 916 & & & \\
\hline
\end{tabular}

a. $R$ Squared $=.279$ (Adjusted $R$ Squared $=.277$ )

Based on the results of the ANCOVA test given in Table 8, there is a significant difference between the pretest scores and the corrected posttest average scores of students in different groups $(\mathrm{F}(914 ; 1)=32.644, \mathrm{p}<0.01)$. Consequently, it can be concluded that teachers' self-efficacy has an effect on students' attitude towards mathematics.

Further ANCOVA tests were conducted on each sub-research question to find out whether this situation was the result of the self-efficacy score or the outcome of a sub-research question regarding self-efficacy in particular.

i. Findings on the sub-research question regarding Attitude towards Mathematics and Teachers' Self-Efficacy for Instructional strategies

Table 9. The Results of the ANCOVA Test on the Changes in Mathematics Attitude Scale Scores based on Teachers' Self-Efficacy for Instructional Strategies

\begin{tabular}{|l|c|c|c|c|c|}
\hline Source & Type III Sum of & sd & Mean Square & F & P \\
\hline Corrected Model & $33864.654 \mathrm{a}$ & 2 & 16932.327 & 178.692 & .000 \\
\hline Intercept & 19942.698 & 1 & 19942.698 & 210.462 & .000 \\
\hline ATTITUDE1 & 30472.964 & 1 & 30472.964 & 321.591 & .000 \\
\hline Instructional & 3370.765 & 1 & 3370.765 & 35.573 & .000 \\
\hline
\end{tabular}




\begin{tabular}{|l|c|c|c|l|l|}
\hline Error & 86607.799 & 914 & 94.757 & & \\
\hline Total & 5185868.000 & 917 & & & \\
\hline Corrected Total & 120472.454 & 916 & & & \\
\hline
\end{tabular}

a. $R$ Squared $=.281$ (Adjusted $R$ Squared $=.280$ )

Based on the results of the ANCOVA test given in Table 9, there is a significant difference between the pre-test scores and the corrected post-test average scores of students in different groups $(\mathrm{F}(914 ; 1)=35.573, \mathrm{p}<0.01)$. Thus, it is possible to say that the teachers' self-efficacy level have an effect on the students' attitude towards mathematics.

ii. Findings on the sub-research question regarding Students' Attitude Towards Mathematics and Teachers' Self-Efficacy for Classroom Management

Table 10. The Results of the ANCOVA Test on the Changes in Mathematics Attitude Scale Test Scores based on Teachers' Self-Efficacy for Classroom Management

\begin{tabular}{|l|c|c|c|c|c|}
\hline Source & Type III Sum of & sd & Mean Square & F & P \\
\hline Corrected Model & $31760.217 \mathrm{a}$ & 2 & 15880.108 & 163.612 & .000 \\
\hline Intercept & 20386.473 & 1 & 20386.473 & 210.041 & .000 \\
\hline ATTITUDE 1 & 30591.827 & 1 & 30591.827 & 315.187 & .000 \\
\hline $\begin{array}{l}\text { Self-Efficacy for } \\
\text { Classroom } \\
\text { Management }\end{array}$ & 1266.327 & 1 & 1266.327 & 13.047 & .000 \\
\hline Error & 88712.237 & 914 & 97.059 & & \\
\hline Total & 5185868.000 & 917 & & & \\
\hline Corrected Total & 120472.454 & 916 & & & \\
\hline
\end{tabular}

a. $R$ Squared $=.264$ (Adjusted $R$ Squared $=.262)$

In accordance with the ANCOVA test results given in Table 10, there is a significant difference between the pre-test scores and the corrected post-test average scores of students in different groups $(\mathrm{F}(914 ; 1)=13.047 \mathrm{p}<0.05)$. Within the light of these findings, it can be concluded that teachers' self-efficacy level in classroom management plays a significant role in students' attitude towards mathematics.

iii. Findings on the Sub-Research Question Regarding Teachers' Self-Efficacy for Student Engagement in Students' Attitude Towards Mathematics 
Table 11. The Results of the ANCOVA Test on the Changes in Students' Mathematics Attitude Scale Scores based on Teachers' Self-Efficacy for Students Management

\begin{tabular}{|l|c|c|c|c|c|}
\hline Source & Type III Sum of & sd & Mean Square & F & P \\
\hline Corrected Model & $33624.274 \mathrm{a}$ & 2 & 16812.137 & 176.933 & .000 \\
\hline Intercept & 20473.687 & 1 & 20473.687 & 215.467 & .000 \\
\hline ATTITUDE1 & 30846.973 & 1 & 30846.973 & 324.637 & .000 \\
\hline $\begin{array}{l}\text { Self-Efficacy for } \\
\text { Student } \\
\text { Engagement }\end{array}$ & 3130.385 & 1 & 3130.385 & 32.945 & .000 \\
\hline Error & 86848.179 & 914 & 95.020 & & \\
\hline Total & 5185868.000 & 917 & & & \\
\hline Corrected Total & 120472.454 & 916 & & & \\
\hline
\end{tabular}

a. $R$ Squared $=.279$ (Adjusted $R$ Squared $=.278$ )

As per the results of the ANCOVA test given in Table 11, there is a significant difference between the pre-test scores and the corrected post-test average scores of students in different groups $(\mathrm{F}(914 ; 1)=32.945 . \mathrm{p}<0.01)$. In consideration of this fact, one can say that teacher's self-efficacy for student engagement affects students' attitude towards mathematics.

\section{Conclusion}

Following the above mentioned tests, it was found that the leadership style of middle school mathematics teachers has no effect on students' achievements and their attitude towards mathematics. Furthermore, this is in line with Somar's (2009) findings, which concluded that the leadership style of high school mathematics teachers did not have a significant effect on students' achievement in mathematics.

Based on the findings of this study, it is possible to claim that middle school mathematics teachers' management style has no impact on students' attitude towards mathematics, which yet again conforms to the findings of Somar (2009) on the relationship between the leadership style of high school mathematics teachers and students' achievement in mathematics.

Teacher self-efficacy can be broadly described as teachers' thoughts about their own capacity with respect to teaching. Perception of teachers with high selfefficacy affects their activities, efforts and work with students (Ashton, 1985; Ashton \& Webb, 1986). Accordingly, it was discovered that teachers' self-efficacy had an impact on students' mathematical achievement. Self-efficacy is particularly related to school learning and similar achievement activities. Researchers have found the effects of self-efficacy on preference, effort, commitment and success of students (Pajares \& Miller 1994; Pajares, 1996, 1997; Schunk \& Pajares, 2002). 
Furthermore, mathematics teachers with high self-efficacy were observed to have a positive effect on students' mathematical achievement. Therefore, selfefficacy of mathematics teachers seems to be the determining factor in their way of teaching and behaviour in class.

i. It was observed that teachers' self-efficacy levels for instructional behaviour did not prove to be a factor in students' mathematical achievement.

ii. It was determined that teachers' self-efficacy for classroom management affected students' mathematical achievement. According to Bandura (1995), teachers that display low self-efficacy have the tendency to create an environment that has an adverse effect on students' mathematical achievement. Bandura (1982) also suggests that, even in a situation where individuals know what they are supposed to do, they are set on the course of failure as a result of low self-efficacy levels.

A mathematics teacher fulfils many functions during the teaching process. While building on students' prior knowledge, the teacher provides the learners with scaffolding, which is a must for students to make of mathematics (Van De Walle, Karp, Bay-Williams, 1998). The classroom environment enables students to establish a connection between what they already know and what they are being taught. In accordance with the findings in this study, it can be claimed that teachers with high self-efficacy are able to create a positive classroom environment. iii. The study showed that teachers' self-efficacy for student engagement did not play a significant role in students' mathematical achievement.

Pajares and Miller (1994) argue that self-efficacy level of teachers is critically important while teaching children with learning disabilities. In addition to that, Ashton and Webb (1986 as cited in Gresham, 2003), state that teachers' selfefficacy perception differs based on the activity; if a teacher feels comfortable with teaching via the direct instruction teaching strategies, he or she is unlikely to employ peer teaching method even if they had prior training in this regard (as cited in Gresham, 2003).

The 2009 mathematics curriculum published by the Ministry National Education İn Turkey is based on the assumption that every individual is capable of learning mathematics. Ashton and Webb (1986) discovered that students are prone to believe in their tendency to learn and that teachers have developed themselves in a way that would ensure students' faith in themselves. These teachers not only offer students a hospitable and encouraging learning environment, but they also sustain the belief that students will behave themselves accordingly, if they are treated equally and coherently. The Mathematics curriculum (MEB, 2009; 2013) is indeed on these principles and standards. High levels of self-efficacy will prevent the discrimination of students as successful or unsuccessful.

Findings in this study suggest that teachers' self-efficacy affecs students' attitude towards mathematics.

This effect was further scrutinized to see whether it was the result of the selfefficacy score or the outcome of a sub-research question regarding self-efficacy in particular. Students transfer ideas in social learning environments to their own psychological upbringing. Internalisation of knowledge can be said to play a role 
in the individual's attitude. Steinkamp (1982) suggested that the basic variables determining achievement in mathematics are math attitudes

i. In the present study, it was found that teachers' self-efficacy for instructional behaviour had a significant effect on students' attitude towards mathematics.

ii. It was found out that teachers' self-efficacy for classroom management had a significant effect on students' attitude towards mathematics.

iii. It was found out that teachers' self-efficacy for student engagement had a significant effect on students' attitude towards mathematics.

Implementation of effective instructional practices in mathematics has been linked to teacher efficacy (Enon, 1995), and highly efficacious teachers are more effective mathematics teachers than teachers with a lower sense of efficacy (Swars, 2005).

Attitudes toward mathematics play a crucial role not only in mathematics education but also in other areas, for example preservice teachers' education (Bursal \& Pozanski, 2006). While research shows that cognitive planning and decision making by teachers has an important contribution to student's learning (Schunk, 2009), we can argue that this also has an effect on students' attitudes. Mohamed and Waheed (2011) when reviewing literature aimed at understanding attitudes and the influences on their development in relation to differences between students, identified factors associated with the school, teacher, and teaching process (e.g., teaching materials, classroom management, teacher knowledge, attitudes towards maths, guidance, beliefs).

\section{Suggestions}

The research can provide a review of middle school mathematics teachers 'necessary aptitude, skills, thinking habits and characteristics in mathematics to improve their own and their students' self-efficacy in mathematics.

The role of mathematics teachers includes the acquisition of mathematical knowledge, identifying obstacles that prevent the acquisition of said knowledge, and develop strategies to overcome adversities in teaching. Furthermore, mathematics teacher need to strengthen their students' positive attitude towards mathematics, while possessing fundamental knowledge in the content domain. Relearning and preparing representations during the cognitive learning process is another role that mathematics teachers are required to have. Therefore, improving one's self-efficacy is an important necessity that full-time and prospective teachers should be taken into consideration for students' mathematical achievement.

It is essential for mathematics teachers to see the mistakes/errors they make as opportunities to further better themselves in the field. For this reason, additional studies regarding self-efficacy in instructional behaviour should be carried out and instructional behaviours should put an emphasis on measures that would help develop teachers' self-efficacy. Mathematics as a science is based on five pillars, which are; self-efficacy, cognitive understanding, operational fluidity, strategic 
competence, reasoning and behaviour. Teachers should be supported with inservice training sessions to reinforce the aforementioned points.

When leadership is considered, it is often the headmaster of a school that comes to mind. However, as with teachers of other subjects, the leadership of the mathematics teacher should be considered and studies should be initiated on this subject. The contemporary mathematics teacher is someone who puts forward the knowledge of mathematics and its sub-domain content, as well as the relationship between these subfields and the Curriculum. As a teaching leader, the mathematics teachers continue to evaluate the process of learning and the students themselves. They play a role in creating an atmosphere and environment that is suitable for learning and teaching. For this reason, studies can be conducted on the contribution of contemporary mathematics teacher as a teaching leader.

Available research shows that teacher can enhance academic performance of learners. Students' greater understanding of concepts can be influenced by motivating students and by using effective strategies related to learning problem and by motivating learners. Every important cognitive act has motivational consequences that potentiate future self -regulatory actions and feelings selfefficacy (Schunk, 1989, 1995; Malpass, O'Neil, \& Hocevar, 1996; Pajares, 1996, 1997; Bandura, 1995). Betz and Hacket (1983) proposed that self efficacy might serve as an important career development mechanism, influencing the educational career decisions, achievement, behaviour, and career adjustment of human. Sense of teacher efficacy is considered to be a variable that influences teacher's action.

Chang (2015) found that fifth-grade mathematics teachers' efficacy significantly influenced both their students' mathematics self-efficacy and mathematical achievement, which was consistent with findings of previous studies (Ashton \& Webb, 1986; Rosenholtz, 1989) linking teacher's mathematical selfefficacy to students' attitudes and abilities.

Students actively participating in a mathematics class tend to believe in the message that "they have the necessary skills to learn math". Therefore, students' self-efficacy can also be investigated. The relationship between students 'selfefficacy and teachers' self-efficacy can be sought. The interrelation between personal and environmental factors can be clearly seen between self and social variables. We can investigate environmental factors, students' self-efficacy, and the effects of parents and family. The roles of mathematical anxiety, perception of self-efficacy towards mathematics and gender variables in predicting mathematics achievement can be investigated. Secondary and high school students' perception of mathematics self-efficacy can be investigated.

We learn mathematics by internalization and mathematical culture in the classroom environments contributes to this process. Hence, further studies aimed on the subject of teachers' mathematical culture can also be carried out.

\section{References}

Aşkar, P., \& Umay, A. (2001). İlköğretim Matematik Öğretmenliği Öğrencilerinin Bilgisayarla İlgili Öz-yeterlilik Algısı. Hacettepe Üniversitesi Eğitim Fakültesi Dergisi, 21, 1-8. 
Andersen, A.M.; Dragsted, S.; Evans, R.H., \& Sorensen, H. (2004). The Relationship between Changes in Teachers' Self-Efficacy Beliefs and the Science Teaching Environment of Danish First-Year Elementary Teachers. Journal of Science Teacher Education, 15(1), 25-38.

Ashton, P.T. (1985). Motivation and the teachers sense of efficacy. In Ames \& R. Ames (Eds.), Research on motivation in education. vol. 2: The classroom milieu (pp. 141171). Orlando: Academic Press.

Ashton, P. T., \& Webb, R. B. (1986). Making a difference: Teachers' sense of efficacy and student achievement. New York: Longman.

Bandura, A. (1977a). Self-efficacy: Toward a unifying theory of behavioral change. Psychological Review, 84(2), 191-215

Bandura, A. (1977b). Social learning theory. Englewood Cliffs, NJ: Prentice Hall.

Bandura, A. (1982). Self-efficacy mechanism in human agency. American Psychologist, $37(2), 122-147$

Bandura, A. (1993). Perceived self-efficacy in cognitive development and functioning. Educational Psychologist, 28, 117-148.

Bandura, A. (1997). Self efficacy: Use exercise of control. New York: Freeman.

Bandura, A. (2001). Social cognitive theory: An agentic perspective. Annual Review of Psychology 52, 1-26.

Bandura, A., \& Cervone, D. (1983). Self-evaluative and self- efficacy mechanisms governing the motivational effects of goal systems. Journal of Personality and Social Psychology, 45(5), 1017-1028.

Bandura, A., \& Cervone, D. (1986). Differential engagement of self-reactive influences in cognitive motivation. Organizational Behavior and Human Decision Processes, 38(1), 92-113.

Bandura, A. (1995). Self-efficacy in changing societies. New York: Cambridge University Press.

Baloglu, N., \& Karadag, E. (2008). Ogretmen yetkinliginin tarihsel gelisimi ve ohio ogretmen yetkinlik olcegi: Turk kulturune uyarlama, dil gecerligi ve faktor yapisinin incelenmesi. [Teacher efficacy and Ohio teacher efficacy scale: adaptation for turkish culture, language validity and examination of factor structure]. Kuram ve Uygulamada Egitim Yonetimi, 56, 571-606.

Betz, N. E., \& Hackett, G. (1983). The relationship of mathematics self-efficacy expectations to the selection of science-based college majors. Journal of Vocational Behavior, 23(3), 329-345.

Bloom, B. S. (1995). İnsan Nitelikleri ve Okulda Öğrenme (Çev.: D.A. Özçelik). Ankara: Milli Eğitim Basım Evi.

Bursal, M., \& Paznokas, L. (2006). Mathematics anxiety and pre-service elementary teachers' confidence to teach mathematics and science. School Science and Mathematics, 106(4), 173- 79

Chang (Aldy), Y.L. (2015). Examining relationships among elementary mathematics teachers' efficacy and their students' mathematics self-efficacy and achievement. Eurasia Journal of Mathematics, Science \& Technology Education, 11(6), 13071320.

Cobb, P. (1994). Where is the mind? Constructivist and sociocultural perspectives on mathematical development. Educational Researcher, 23(7), 13-20.

Deniz, L., \& Hasançebioğlu, T. (2003). Öğretmen liderlik stillerini belirlemeye yönelik bir ölçek çalışması. Marmara Üniversitesi Eğitim bilimleri dergisi, sayı.17. sayfa:55-62.

Denise, H., \& O'Neil, H. F. (1997). The Role of Parental Expectation, Effort, and Self efficacy in the Achievement in the High and Low Track High School Students in 
Taiwan, Paper Presented at the Annual Meeting of the American Educational Research Association, Chicago.

Eden, D., \& Aviram, A. (1993). Self-efficacy training to speed reemployment: Helping people to help themselves. Journal of Applied Psychology, 78(3), 352-360.

Enon, J.C. (1995). Teacher efficacy: Its effects on teaching practices and student outcomes in mathematics, Unpublished doctoral dissertation. University of Alberta, Bloomington, IN.

Eurydice (2011). Avrupa'da temel matematik eğitimi: temel zorluklar ve ulusal politikalar. http://eacea.ec.europa.eu/education/eurydice/ Eurydice Avrupa Eğitim Bilgi Ağı Türkiye Birimi: http://sgb.meb.gov.tr

Friedman, I.A., \& Kass, E. (2002). Teacher self-efficacy: a classroom organization conceptualization. Teaching and Teacher Education, 18(6), 675-686.

Gibson, S., \& Dembo, M.H. (1984). Teacher efficacy: a construct validation, Journal of Educational Psychology, 76(4), 569-582.

Gresham, D.E. (2003). Establishing the technical adequacy of functional behavioral assessment: Conceptual and measurement challenges. Behavioral Disorders, 28(3), 282-298

Huinker, D., \& Madison, S.K., (1997). Preparing efficacious elementary teacher in science and mathematics: The influence of method courses. Journal of Science Teacher Education, 8(2), 107-126

Kağıtçıbaşı, Ç. (1979). İnsan ve İnsanlar. (3. Basım). İstanbul: Evrim Basın Yayın Dağıtım.

Karasar, N. (2007). Bilimsel Araştırma Yöntemleri, 17. Basım, Ankara

Malpass, J., O'Neil, H.F., \& Hocevar, D. (1996). Self-regulation, goal orientation, selfefficacy and math achievement. Paper presented at the Annual Meeting of the American Educational Research Association, Newyork.

Milli Eğitim Bakanlığı (MEB) (2009). Ortaöğretim Matematik Dersi (5-8. Sınıflar) Öğretim Programı. Ankara: Mili Eğitim Basımevi. https://bit.ly/3kHysNG.

Milli Eğitim Bakanlığı (MEB) (2013). Ortaöğretim Matematik Dersi (5-8. Sınıflar) Öğretim Programı. Ankara: Mili Eğitim Basımevi.

Mohamed, L., Waheed, H. (2011). "Secondary students' attitude towards mathematics in a selected school of Maldives." International Journal of Humanities and Social Science, 1(15), 277-281.

Nazlıçiçek, N. ve Erktin, E. (2002). İlköğretim Öğretmenleri İçin Kısaltılmış Matematik Tutum Ölçeği. V. Ulusal Fen Bilimleri ve Matematik Eğitimi Kongresi Bildiri Kitapçığı (16-18 Eylül 2002), 860-865. Ankara: Orta Doğu Teknik Üniversitesi.

Pajares, F. (1996). Self-efficacy beliefs in achievement settings. Review of Educational Research, 66(4), 543-578.

Pajares, F. (1997). Current directions in self-efficacy research. In M. Maehr \& P. R. Pintrich (Eds.), Advances in motivation and achievement vol. 10, (pp. 1-49). Greenwich, CT: JAI Press.

Pajares, F., \& Miller, M. D. (1994). The role of self-efficacy and self-concept beliefs in mathematical problem solving: A path Analysis. Journal of Counseling Psychology, 86(2), 193-203.

Reyes, L.H. (1984). Affective variables and mathematics education. The Elementary School Journal, 84(5), 558-581.

Rosenholtz, S. (1989). Teacher's workplace: The social organization of schools. White Plains, NY: Longman.

Schunk, D. IT. (1989). Self-efficacy and cognitive skill learning. In C. Ames \& R. Ames (Eds.), Research on motivation in Education, vol. 3: Goals and cognitions (pp. 1344). San Diego: Academic Press. 
Schunk, D.H. (1995). Self-efficacy' and education and instruction. In J. E. Maddux (Ed.), Self-efficacy adaptation, and adjustment: Theory research, and applications (pp. 281303). New York: Plenum.

Schunk, D.H., \& Pajares, F. (2002). The development of academic self-efficacy. In A. Wigfield Bi J. S. Eccles (Eds.), Development of Academic Motivation (pp. 15-31). San Diego: Academic Press.

Schunk, D.H. (2009). Learning Theories an Educational Perspective, $5^{\text {th }}$ ed. New Jersey: Pearson Education, Inc.

Somar, A. (2009). Ortaögretimdeki Matematik öğretmenlerinin liderlik stillerinin ögrencilerin Matematik dersindeki başarı ve tutumu üzerine etkileri. (Yüksek Lisans Tezi, Yeditepe Üniversitesi, 2009). YÖK Dökümantasyon Merkezi (No. 234805).

Stajkovic, A.D., \& Luthans, F. (1998). Self-efficacy and work-related performance: A metaanalysis, Psychology Bulletin, 124(2), 240-261.

Steinkamp, M.W. (1982). Sex-related differences in attitude toward science: A quantitative synthesis of research. Paper presented in the Annual meeting of the American Educational Research Association, New York.

Swars, S.L. (2005). Examining perceptions of mathematics teaching effectiveness among elementary preservice teachers with differing levels of mathematics teacher efficacy. Journal of Instructional Psychology, 32(2), 139-147.

Tschannen-Moran, M., Hoy, A.W., \& Hoy, W.K. (1998). Teacher efficacy: Its meaning and measure. Review of Educational Research, 68(2), 202-248.

Tschannen-Moran, M., \& Woolfolk-Hoy, A.E. (2001). Teacher efficacy: Capturing and elusive construct. Teaching and Teacher Education, 17, 783-805.

Tuckman, B.W., \& ve Sexton, T.L. (1990). The Relationship Between Self- Beliefs And Self Regulated Performance. Journal of Social Behavior and Personality, 5, 465472.

Tuluk, G., (2015). Öğretmen Adaylarının Öğretmen Öz Yeterlilikleri Üzerine Bir İnceleme, Uşak Üniversitesi Eğitim Araştırmaları Dergisi, Cilt I, Sayı I, 1-15. Uşak

Van de Walle, J.A., Karp, K.S., \& Bay-Williams, J.M. (1998). Elementary and Middle School Mathematics Teaching Developmentally. New York: Addison Wesley Longman, Inc. 
